\title{
Business Incubator Model in Support Makassar State University Edupreneur
}

\author{
Muhammad Farid ${ }^{1}$, Muh. Ihsan Said Ahmad ${ }^{2, *}$, Syamsuardi $^{3}$, Aris Baharuddin ${ }^{4}$, \\ Muhammad Hasan ${ }^{2}$ \\ ${ }^{1}$ Department of Automotive Engineering Education, Faculty of Engineering, Universitas Negeri Makassar \\ ${ }^{2}$ Department of Economics Education, Faculty of Economics, Universitas Negeri Makassar \\ ${ }^{3}$ Department of Early Childhood Education Programs, Faculty of Science Education, Universitas Negeri Makassar \\ ${ }^{4}$ Department of Business Administration, Faculty of Social Sciences, Universitas Negeri Makassar \\ *Corresponding author.Email: m.ihsansaid@unm.ac.id
}

\begin{abstract}
One of the entrepreneurship programs that have a strategic role in realizing these goals is to streamline the role of business incubators. The purpose of this study is to (1) examine the results of the initial investment needed for a business incubator model to support edupreneurs at UNM, (2) examine the results of the design of a business incubator model in supporting edupreneurs at UNM, and (3) examine the results of the business incubator model in supporting edupreneur at UNM. This study is a development research, namely the development of a business incubator model. The study was conducted at Makassar State University (UNM). The subjects in this study were the head of the LIPK institution and the manager of the business incubator as well as the tenants who participated in the incubator fostered as many as 20 tenants. The results of the study obtained are the Training Center and Business Incubator (PPIB) as part of the Institute for Entrepreneurship Innovation and Development (LIPK) which aims to create a new mindset for students to become entrepreneurs and increase knowledge and experience in managing and building businesses. To realize these goals and objectives, a work program for the development of the Education Center and Business Incubator is formed as follows: 1) An edu-prenership-based entrepreneurship training program that is planned and integrated for UNM students and alumni as well as MSME partners. 2) Systematic business incubator program for students, alumni and SMEs through pre-incubation, incubation and post-incubation entrepreneurship. 3) Business consulting services, mentoring (coaching) and facilitation of training programs and entrepreneurship incubators 4) Effective partnerships with various interested parties (Stakeholders).
\end{abstract}

Keywords: Business Incubator Model, Edupreneur

\section{INTRODUCTION}

The government's policy on entrepreneurship development has existed since 1995 and continues to this day. Initially, this policy instructed all components of the Indonesian nation to develop entrepreneurship programs in various aspects. Through this movement, it is hoped that entrepreneurship can become part of the work ethic of the Indonesian people and nation, thus giving birth to new, reliable entrepreneurs who can see opportunities and come up with innovative, tough and independent ideas.

The ultimate goal of this policy is to accelerate the achievement of national development goals in increasing prosperity and justice in society and to align Indonesia as a country that has advanced from the indicator of the number of entrepreneurial economic actors who drive the wheels of its national economy. One of the entrepreneurial programs that have a 
strategic role in realizing these goals is to streamline the role of business incubators.

The results of the National Socio-Economic Survey (Susenas) by the Central Statistics Agency (BPS) in March 2010 stated that the number of poor people in Indonesia was 39.05 million or 17.75 percent of the total 222 million population. Indonesia's poor population increased by four million people compared to that recorded in February 2009. The unemployment rate is in the range of $10.8 \%$ to $11 \%$ of the workforce which is categorized as open unemployment. Even those who graduate from college are finding it increasingly difficult to find work because there is not much expansion of business activities. Under these circumstances, the problem of unemployment, including those with higher education, will have a negative impact on economic, social and social stability.

This condition is also supported by the fact that most university graduates are more job seekers than job creators. This could be because the current academic and learning system applied in higher education does not prepare graduates who are ready to create jobs. Entrepreneurial activity index is translated as an active individual in starting a new business and is expressed as a percentage of the total population actively working. The higher the Entrepreneurial activity index, the higher the level of entrepreneurship of a country [1].

In 1997, 29 New Entrepreneur Incubators (INWUB) were developed. Most of them are university programs. In 2004, of the 56 incubator units in Indonesia, only a few were active. The program has not produced many alumni who are proven to be more competitive in the world of work [2]. Not all Business Incubators can develop as expected. Of the hundreds of incubators that have ever grown in Indonesia, now there are only around 50. Most of them are in poor condition. Constraints faced include the lack of support and coordination of related institutions, especially supporting facilities and funds [3].

The business incubator is a very important medium for entrepreneurs, especially for business startups in developing their business or entrepreneurship. Entrepreneurs who become tenants of business incubators will participate in a series of incubation programs that have been prepared and become programs from business incubators to improve entrepreneurial skills.

According to Entrepreneur Asia Pacific, a business incubator is a program or organization that provides sponsorship with the aim of accelerating the growth and success of a startup or business [4]. This program will help new start-ups in their early stages of development by providing connections to angel investors, governments, economic development coalitions, and other investors so that the businesses to be formed will have sufficient capital to build a business. In fact, it is possible for the business incubator itself to provide capital loans for a business. In addition to providing assistance in terms of capital, this program also helps start-up businesses in terms of work facilities, training, mentoring, and much more. A business incubator will help direct a small-scale company to be formed with good organizational and financial management. The hope is that the business can work and develop sustainably and generate the desired profit [5].

There are several models that need to be considered in developing a business incubator model. First, the model developed by Lacho, [6] when developing the "Entrepreneurship Education" model at the University of New Orleans (UNO) for two seasons. Skills that are taught specifically about building networking and negotiation skills, as well as full skills that are mastered by company employees. Only 10 students participated in the model development. As a result, all students were able to pass well. Researchers implement entrepreneurship by making small business ventures on campus. Of the 10 students, there are those who act as internal and external parties to the company. The internal roles that must be played are: business owners, workers, leaders, and supervisors. External parties that must be played include: customers, banks, suppliers (suppliers), media, and others. Networking and negotiation skills should be developed during the practice of the venture. As a result, this method turned out to be more effective and applicable in real situations.

Second, the model developed [7], while conducting research on, "Origins of entrepreneurial Opportunities in e-Banking." The model developed takes one of the models used by Plummer [7] which describes that the development of an entrepreneurial model can be started by: feeling the existence of entrepreneurial opportunities, developing entrepreneurial strategies, determining new opportunities that can be done to start a business, and executing those opportunities in the form of exploitation of businesses that are believed to be profitable.

Third, Ardichvili et.al Model [7]. This model is more complicated than the Plummer model. To grow entrepreneurial abilities, it is necessary to: trait, namely a treatment to appear personal creativity and optimism, form a social network, by trying to overcome selfweaknesses, make a number of actions (action sets), look for work partners (partnership), processing skills continuously, preparing an entrepreneurial spirit (entrepreneurial alertness), as the core process (core process) is to build a good perception (perception), find interesting things (discovery), create innovations that can bring profit (creation). When it has been created, it remains only to develop (development), and evaluate its strengths and weaknesses, to be developed in a better 
form in the future (future formation) by taking into account the various types of opportunities that exist.

Fourth, the model developed by [8] which has been adapted by Lacho [8] is to invite students to watch videos (films) to practice some important concepts about entrepreneurship, so that students develop an entrepreneurial mind set. It is very important to cultivate an entrepreneurial mind set in the student's soul, so that all thoughts, feelings, actions, speech, discussions, daily life behaviors, and the whole process of activities in all forms of activity are always business-oriented [9].

Fifth, the model developed in conducting research entitled, Development of Entrepreneurship Education Learning Design in Higher Education with Modeling of Successful Small and Medium Business Entrepreneurs produces an entrepreneurial learning model for kindergarten and elementary school students [10]. The results of the study concluded that to develop an entrepreneurial spirit requires a long time, therefore it needs to be introduced, motivated, and instilled from an early age, starting from the education that is instilled in the family, which emphasizes the importance of discipline and independence. The introduction of success stories from entrepreneurs can be done to students from the elementary school level to even kindergarten.

Sixth, the model developed by Alma [11] that, "Starting new entrepreneurial ventures can be described through the processes and characteristics of people who have the potential to become rich."

Universities and several other institutions in Indonesia have been facilitated by various ministries since 1995 with the existence of entrepreneurship development programs and business incubators that offer various activities, namely Entrepreneurship courses. The entrepreneurship education curriculum generally contains materials and activities related to building an entrepreneurial mental attitude, practicing communication skills, building networks and preparing profit-oriented business plans [12]. Including the establishment and development of business incubators. So it is not surprising when a university has an entrepreneurship unit and a business incubator institution for the benefit of the campus academic community.

To support this, Makassar State University has run various entrepreneurship programs, both in the form of lectures, seminars, and training, as well as in the form of mentoring and business incubators for alumni and entrepreneurial students. This is also a form of implementation of the Makassar State University (UNM) vision, namely "As a Center for Education, Assessment and Development of Education, Science, Technology, and the Arts, with Education and Entrepreneurship perspectives". With this vision, UNM is a university, one of which will focus on creating edupreneurs for students and alumni.

In realizing this vision, since 2020 UNM has formed a separate institution that focuses on entrepreneurship programs, namely the Institute for Entrepreneurship Innovation and Development (LIPK). One of the implementing units for the entrepreneurship program under LIPK is the Business Training Center and Incubator. The existence of the UNM business incubator institutional unit is expected to be able to help realize UNM's vision in the field of entrepreneurship development for the academic community in all units and faculties at UNM.

As a follow-up to these expectations, a need analysis of a productive, feasible and effective Business Incubator model is needed according to the needs of entrepreneurial students. With this, it is hoped that the results of this incubator model can be applied and developed through strategies, steps, principles of developing business incubators that are effectively and productively used in growing and developing student entrepreneurs that will be or are being run.

ased on the background exposure, the aims of the researcher are to (1) examine the results of the initial investment needed for the business incubator model to support edupreneurs at UNM, (2) examine the results of the business incubator model design in supporting edupreneurs at UNM, and (3) examine the results of the incubator model business in supporting edupreneurs at UNM.

\section{METHOD}

This study is a development research, namely the development of a business incubator model with reference to the developed model which consists of: Starting with reviewing and analyzing policies related to the subject matter. Then look at the facts of application in the field situationally based on data and information on previous activities [13]. Through a descriptive analysis approach and limited discussion on the holding of Workshops and Business Meetings, a business incubator model was developed for the development of business incubator institutions in the future.

The study was conducted at Makassar State University (UNM). The subjects in this study were the head of the LIPK institution and the manager of the business incubator as well as the tenants of the incubator fostered participants who were used as research subjects as many as 20 tenants.

The design activities in each phase are presented as follows:
a. Initial investigation (preliminary study)
b. Design
c. Realization 

d. Testing, evaluation and revision
e. Implementation

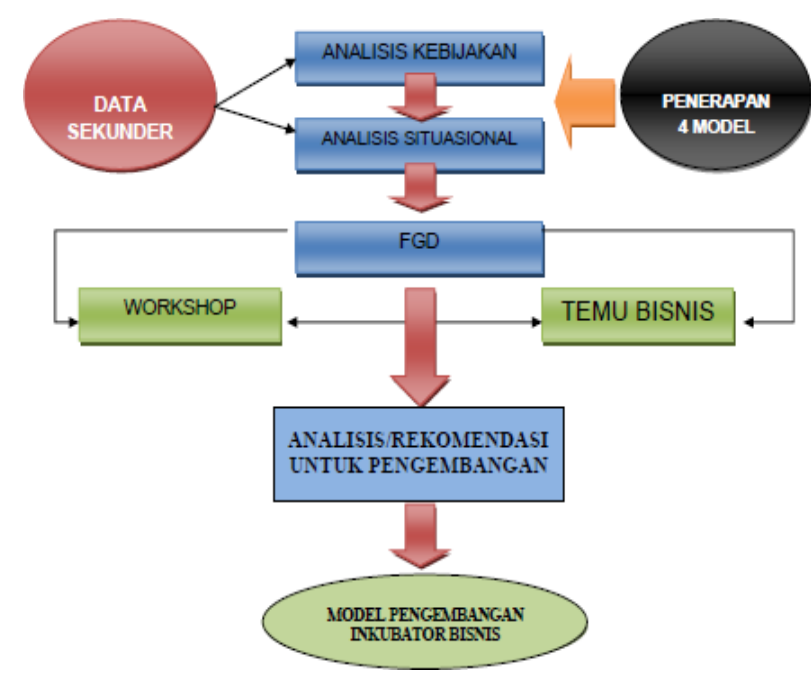

Figure 1. Business Incubator Model Development Phases

The instruments used in this study, namely: (a) validation sheet, (b) model assessment sheet and its feasibility for use, (c) observation sheet, (d) tenant and manager response questionnaire, and (e) incubation results evaluation sheet. While the data analysis technique used the feasibility/validity data analysis technique, practicality data analysis, and effectiveness data analysis.

\section{DISCUSSION}

\subsection{Policy Review and Analysis}

The direction of the Development Strategy at the Ministry of Cooperatives and MSMEs in 2020-2024, one of which is the development of human resources and the business incubator program which must be the main focus for creating new entrepreneurs. This is to increase Indonesia's economic growth from the entrepreneurial sector. This strategic direction is the embodiment of the Ministerial Regulation (PERMEN) of Cooperatives and MSMEs RI Number 24/Per/M.KUKM/IX/2015 concerning Norms, Standards, Procedures and Criteria for the Implementation of Entrepreneurial Incubators. And it is also a derivative of Presidential Regulation (PERPRES) Number 27 of 2013 concerning Entrepreneurial Incubator Development.

One of the contents of the framework of strategic activities in entrepreneurship development in 2021 is the development of the Entrepreneurship Incubator and at the same time this entrepreneurship incubator becomes one part of the entrepreneurship ecosystem in addition to regulations including information and education.

\subsection{Entrepreneurship Development at Makassar State University}

Entrepreneurship education at universities is an effort to improve the standard of living of the Indonesian people through improving the quality of human resources as the support for the nation's economy [13]. This has become one of the main concerns of the Ministry of Research, Technology and Higher Education, where since 1997 various programs have been held, including Entrepreneurship Education (KWU), Entrepreneurship Internships (MKU), Business Work Courses (KKU), Business Consulting and Work Placement (KBPK), Program Student Entrepreneurship (PMW), New Entrepreneur Incubator (INWUB), Entrepreneurship Student Creativity Program (PKM-K) and Indonesian Student Entrepreneurship Program (PKMI). All of these programs are implemented in an effort to improve the quality of higher education graduates by implementing abilities, skills, attitudes of responsibility, building teamwork as well as developing independence and developing business through creative activities in the field of knowledge they are engaged in. This is in line with Government Regulation No. 17 of 2010 which states that the goals of higher education are, among others, to form people who are critical, creative, innovative, independent, confident and have an entrepreneurial spirit.

The university is expected to be able to encourage and produce alumni who have an entrepreneurial spirit and can play an active role in advancing the nation's economy. In line with this, in order to realize the vision and mission of Makassar State University "as a center for education, study and development of education, science, technology, and arts with an educational and entrepreneurial perspective". UNM is expected to be able to organize Tridharma activities to produce professional human resources in the field of education and non-education with an entrepreneurial perspective. One of the concrete steps taken is to provide a provision of understanding related to entrepreneurship in the form of compulsory entrepreneurship courses in each study program for all educational strata owned, with the hope that UNM alumni can form an entrepreneurial spirit and become entrepreneurs in developing businesses in the community.

Efforts have been made to achieve the vision and mission, since 2010 UNM has established a Technical Implementation Unit (UPT) for Entrepreneurship. The existence of this unit is expected to be a trigger in accommodating entrepreneurship programs that involve the UNM academic community. Several programs that have been implemented are to accommodate student participation in the Student Entrepreneurial Program (PMW) and the opening of business units as well as entrepreneurship training/workshops. 
Furthermore, based on the vision of the Chancellor of UNM, Prof. Dr. Ir. H. Husain Syam, M.TP., IPU., ASEAN Eng., declared UNM as an entrepreneur university, so a new institution was formed that was able to encourage the acceleration of entrepreneurship development at UNM. In 2020, UNM established the Institute for Entrepreneurship Innovation and Development (LIPK) of Makassar State University, which became the center for the development of entrepreneurship programs, and as a business center that can provide income generation, in support of changing UNM's status from higher education in the Work Unit (Satker) category to a Business Unit. Public Service (BLU).

Entrepreneurship development program, LIPK UNM is present in accommodating learning, research and innovation study programs to prepare students with entrepreneurial spirit, facilitating those who want to start business start-ups, and providing services to alumni who already have businesses and the community of Micro, Small and Medium Enterprises (MSMEs). SMEs) through training and business development programs.

LIPK UNM contributes to the development of research that can encourage the downstream process of research results for the development of innovations and products that can take the form of partnerships between universities and industry. This partnership program is expected to produce a superior product, mass-produced, and can contribute to improving the nation's economy and welfare.

\subsection{Makassar State University Business Incubator}

Implementing the duties and responsibilities of LIPK UNM are entrusted to the Chair and Secretary who come from Lecturers (Educators) who get Additional Tasks. In addition to the Chair and Secretary, there are also 4 (four) Heads of Center who act as the person in charge of the program, consisting of the Head of the Center for Curriculum Development and Entrepreneurship Module, Head of the Training Center and Business Incubator, Head of Research, Innovation and Product Development Center, and Head of the Business Development Center. and administrative staff. The business incubator is a sub-section of the Training Center and Business Incubator of LIPK UNM.

The Business Incubator and Training Center (PPIB) as part of the Institute for Entrepreneurship Innovation and Development (LIPK) has the goal of realizing UNM's vision through the implementation of planned and systematic entrepreneurship training and conducting a business incubator process for the academic community. PPIB aims to create a new mindset for students to become entrepreneurs and increase knowledge and experience in managing and building a business. To realize these goals and objectives, a work program for the development of the Education Center and Business Incubator is formed as follows: 1) An eduprenership-based entrepreneurship training program that is planned and integrated for UNM students and alumni as well as MSME partners. 2) Systematic business incubator program for students, alumni and SMEs through pre-incubation, incubation and post-incubation entrepreneurship. 3) Business consulting services, mentoring (coaching) and facilitation of training programs and entrepreneurship incubators 4) Effective partnerships with various stakeholders (Stakeholders).

\subsection{LIPK Business Incubator Model Design supports Edupreneure UNM}

This research will also refer to the model developed by Plomp (1997), which consists of (a) preliminary investigation phase, (b) design phase (design), (c) realization/construction phase (realization/construction), (d) the test, evaluation and revision (test, evaluation and revision) phase, and (e) the implementation phase. The Plomp model was chosen in this study based on considerations, this model is seen as more flexible and flexible than other models.

The scheme of the Incubator model UNM is as follows:

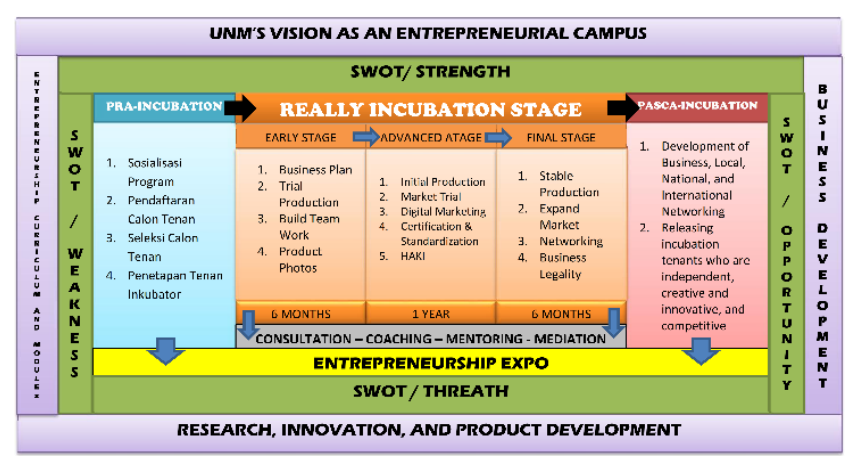

Figure 2. UNM Incubator Model Schematic

\section{CONCLUSION}

Entrepreneurship development program, LIPK UNM is present in accommodating learning, research and innovation study programs to prepare students with entrepreneurial spirit, facilitating those who want to start business start-ups, and providing services to alumni who already have businesses and the community of Micro, Small and Medium Enterprises (MSMEs). SMEs) through training and business development programs. LIPK UNM contributes to the development of research that can encourage the downstream process of research results for the development of innovations and products that can take the form of partnerships between universities and industry. 
The Business Incubator and Training Center (PPIB) as part of the Institute for Entrepreneurship Innovation and Development (LIPK) has the goal of realizing UNM's vision through the implementation of planned and systematic entrepreneurship training and conducting a business incubator process for the academic community. PPIB aims to create a new mindset for students to become entrepreneurs and increase knowledge and experience in managing and building a business. To realize these goals and objectives, a work program for the development of the Education Center and Business Incubator is formed as follows: 1) An eduprenership-based entrepreneurship training program that is planned and integrated for UNM students and alumni as well as MSME partners. 2) Systematic business incubator program for students, alumni and SMEs through pre-incubation, incubation and post-incubation entrepreneurship. 3) Business consulting services, mentoring (coaching) and facilitation of training programs and entrepreneurship incubators 4) Effective partnerships with various interested parties (Stakeholders).

\section{ACKNOWLEDGMENTS}

We would like to express our deepest gratitude to the Head of Rektor Universitas Negeri Makassar, as well as friends who have provided support for the implementation of this research.

\section{REFERENCES}

[1] Aliami, Sri., Ema Nurzainul H., Diah Ayu, and Septi Alberti, F., Salvatore S. dan Alberto P. 2004, Entrepreneurship Education: Notes on and Ongoing Debate, 14thAnnual int. Ent. Conference, University of Napoli Federico II (Italy) 4-7 July 2004

[2] Ardichvili, A.; Richard C. dan Sourav R. 2003: A theory of Entrepreneurial opportunity identification and development, Journal of Business Venturing, Vol. 18 pp. $105-123$.

[3] Kuratko, D. F. 2004, Entrepreneurship Education in the 21st Century: from Legitimization to Leadership, A Coleman Foundation White Paper USASBE National Conference, January 16, 2004

[4] Powers, J. B dan Patricia P. McDougall, 2005, University Start-up Information and Technology Licensing with Firms that Go Public: a ResourceBased View of Academic Entrepreneurship, Journal of Business Venturing No 20 (2005), pp. 291-311.

[5] Brouwer, M. T., 2002 Weber, Schumpeter, and Knight on Entrepreneurship and Economic Development, Journal of Evolutionary economics, Springer, Verlag, Vol. 12, 2002, pp 83-105.

[6] Lacho, K. 2010, Entrepreneurship Education: Another Approach, Small Business Institute Journal, Vol. 5. April 2010 pp 67—82.

[7] Kordnaeij, et.al., 2011, origins of entrepreneurial Opportunities in e-Banking, Journal of Global
Entrepreneurship Research, Winter \& Spring, 2011, Vol.1 No. 1 pp 21-33

[8] Mohammad. A. S. (2012). The Measurement of Entrepreneurial Personality and Business Performance in Trenggano Creative Industry, International Journal of Business and Management, 6 (6), 183-192.

[9] Naughton, M. dan Jeffry C. 2009, Culture as the Basis of The Good Entrepreneur, Journal of Religion and Business Ethics, Vol. 1, Issue I, article 2. 2009

[10] Stevenson, H. H. 2000, Why entrepreneurship has won!, Coleman White paper, USASBE Plenary Address, February 17, 2000

[11] Alma, B. 2003. Kewirausahaan. Bandung: Alfabeta.

[12] Maria, M., \& J. P.A., Cuato. (2012). The triple helix model and dynamics of innovation: a case study, Journal of Knowledge-based Innovation , 4 (1), 3654.USA National Business Incubation Association 2011.

[13] Dikti, Depdiknas, 2008, Materi TOT Soft Skill, Hotel Pangrangon Bogor tanggal 28-30 November 2006 